\title{
A Study on Customer Perception towards DTH Services in Coimbatore City
}

\author{
*J.Jayashree, **A.Sivakumar \\ * (Asst. Professor, Commerce, Dr.SNS Rajalakshmi College of arts and science, Coimbatore, India) \\ ** (Head \& Professor, Commerce, Dr.SNS Rajalakshmi college of arts and science, Coimbatore, India)
}

\begin{abstract}
In the buyer's market today, business concerns have to make a lot of efforts to sell their product and establish their survival. It may be basically due to changes in attitude of consumers towards buying products and changing business world. Every human being is changing time to time according to the changing trends in every day's life. The biggest changes occurred in consumer products, new and innovative technology has used to satisfy the consumers. In this content the study is taken up with the various DTH services which have considerable share in the market. This paper reveals the customer perception towards DTH services in Coimbatore city and it also helps to analyze the competition exist in the market regarding DTH services. The study is focused on the four kinds of DTH services namely, Sun direct, TATA sky, Dish TV, Big TV. The task of the study is to know the preference of the users in Coimbatore city among these various services. Various tools used to analyse the data. The present study reveals that the majority of the respondents prefer to buy sun direct because of its best picture quality, reasonable price, various kinds of packages and more channels. So the DTH service providers must pay attention on Customer Service, picture quality, reasonable price rather than other factors to make their business more successful and satisfy the consumers
\end{abstract}

Keywords: Awareness, Customer service, DTH channels, schemes etc.,

\section{Introduction}

In the buyer's market today, business concerns have to make a lot of efforts to sell their product and establish their survival. It may be basically due to changes in attitude of consumers towards buying products and changing business world. It is also true that consumers vary tremendously in age, income, education, living pattern and preference. Thus buyer's behavior plays a key role for the success of any business in today's business life. Consumer buying behavior is influenced by culture, social, personal and psychological factors. The cultural factors exert the broadest and deepest influence.

\section{Direct-To-Home Television}

DTH is defined as the reception of satellite programmes with a personal dish in an individual home, and an individual set top box empowering you to pick \& choose bundles of choice and pay for what you watch. DTH services were first proposed in India in 1996.But they did not pass approval because there were concerns over national security and a cultural invasion. In 1997, the government even imposed a ban when the Rupert Murdoch-owned Indian sky Broadcasting (ISKYB) was about to launch its DTH services in India.

\section{Objectives of the Study}

$>$ To analyze the perception of users towards DTH services in Coimbatore city

$>$ To study the source of awareness about the DTH service

$>$ To study the level of satisfaction about DTH service

$>$ To identify the factors motivating the subscribers to purchase the DTH.

\section{Statement of Problem}

Every human being is changing time to time according to the changing trends in every day's life. The biggest changes occurred in consumer products, new and innovative technology has used to satisfy the consumers. In this content the study is taken up with the various DTH services which have considerable share in the market. Consumers and buyers play a vital role in the market. Some of the problems faced by the DTH users are less quality of dish and are, not providing more free channels, less clarity, high subscription amount and unable to see the local channels and so on. So this study helps to find out the consumer attitude towards DTH users. 


\section{Scope of the Study}

The present study helps to analyze the competition exist in the market regarding DTH services. The scope of the study also covers the key factors which influences the customer to take decisions to buy DTH connection for television. The study is focused on the four kinds of DTH services namely, Sun direct, TATA sky, Dish TV, Big TV.

The task of the study is to know the preference of the users in Coimbatore city among these various services.

\section{Methodology And Research Design}

The Methodology and design adopted for the study was as follows:

\section{Sources of Data}

The primary objective of the study is to ascertain the customer perception towards DTH services in Coimbatore City. The study is mainly based on primary data. The primary data was collected through the questionnaires administered to different types of selected sample respondents. The secondary information's were collected from different sources like newspapers, magazines, journals, books, websites, pamphlets and so on., for which the researcher approached various institutions like. Bharathiar University Library and PSG School of Management, Coimbatore and so on.

\section{Statistical Tools Used For Analysis}

The primary data have been collected from the potential respondents from different areas and has been properly sorted, classified, edited, tabulated in a proper format and analyzed by deploying appropriate statistical tools. The statistical tests are conducted at 5 per cent and 1 per cent level of significance. The following statistical tools are used.

$>$ Descriptive Analysis.

$>$ Chi-square test.

$>$ Garrett Ranking Techniques.

$>$ Reliability test

\section{Sampling Techniques}

For the purpose of analysis, the data has been collected from three hundred customers from the selected sampled Respondents in Coimbatore City. The samples have been selected on the basis of convenient random sampling techniques. The data has been tabulated and statistically interpreted whenever and wherever needed

\section{ANALYSIS \& INTERPRETATION}

TABLE 1

DTH AT PRESENT IN YOUR HOME

\begin{tabular}{|l|c|c|c|c|}
\hline \multicolumn{1}{|c|}{ DTH SERVICE } & $\begin{array}{c}\text { NO. OF } \\
\text { RESPONDENT }\end{array}$ & $\begin{array}{c}\text { PERCENTAGE } \\
(\boldsymbol{\%})\end{array}$ & MEAN & S.D. \\
\hline Sun direct & 182 & 60.7 & 2.19 & 0.735 \\
\hline Big TV & 53 & 17.7 & 2.34 & 0.678 \\
\hline Digital TV & 24 & 8.0 & 2.50 & 0.511 \\
\hline Dish TV & 29 & 9.7 & 2.21 & 0.774 \\
\hline Tata sky & 6 & 2.0 & 3.00 & 0.000 \\
\hline Others & 6 & 2.0 & 1.00 & 0.000 \\
\hline Total & 300 & 100.0 & 2.23 & 0.731 \\
\hline
\end{tabular}

Source: Primary Data

The table states that 60.7 per cent of the respondents having sun direct in their homes, with the mean and standard deviation of 2.19 and $0.735,17.7$ per cent of the respondents having BIG TV with the mean and standard deviation of 2.34 and $0.678,8$ per cent of the respondents having DIGITAL TV with the mean and standard deviation of 2.50 and $0.511,9.7$ per cent of the respondents having DISH TV with the mean and standard deviation of 2.21 and 0.774 , and only 2 per cent of the respondents having TATA SKY in their homes with the mean value of 3 .

Majority of the respondents $(60.7 \%)$ having sun direct in their homes. 
TABLE 2

TYPE OF PACKAGE

\begin{tabular}{|c|l|c|c|}
\hline S.NO. & $\begin{array}{c}\text { TYPE OF } \\
\text { PACKAGE }\end{array}$ & $\begin{array}{c}\text { NO. OF } \\
\text { RESPONDENTS }\end{array}$ & $\begin{array}{c}\text { PERCENTAGE } \\
(\boldsymbol{\%})\end{array}$ \\
\hline 1 & Family pack & 213 & 71.0 \\
\hline 2 & South value pack & 42 & 14.0 \\
\hline 3 & South started & 12 & 4.0 \\
\hline 4 & Super saver & 28 & 9.3 \\
\hline 5 & Others & 5 & 1.7 \\
\hline \multicolumn{2}{|l}{} \\
Tource: Primary Data
\end{tabular}

The above table shows that 71 per cent of the respondents prefer family pack, 14 per cent of them prefer south value pack, 4 per cent of them prefer south started pack, 9.3 of them prefer super saver pack and 1.7 per cent of them prefer others.

Majority $(71 \%)$ of the respondents prefer family pack.

TABLE 3

SATISFACTION OF BRAND

\begin{tabular}{|c|c|c|c|}
\hline S.NO. & $\begin{array}{c}\text { SATISFACTIO } \\
\text { N }\end{array}$ & $\begin{array}{c}\text { NO. OF } \\
\text { RESPONDENTS }\end{array}$ & $\begin{array}{c}\text { PERCENTAGE } \\
(\%)\end{array}$ \\
\hline 1 & Highly satisfied & 123 & 41 \\
\hline 2 & Moderate & 18 & 6 \\
\hline 3 & Satisfied & 159 & 53 \\
\hline & Total & 300 & 100 \\
\hline
\end{tabular}

Source: Primary Data

The table implies that 41 per cent of the respondents highly satisfied with the brand, 6 per cent of them are moderately satisfied, and 53 per cent of them are satisfied with the usage of brand.

Majority (53\%) of them are satisfied with the usage of brand.

\section{GARRETT RANKING TECHNIQUES}

TABLE 4

REASONS BEHIND SELECTING THE DTH SERVICES

\begin{tabular}{|c|l|c|c|c|}
\hline $\begin{array}{c}\text { S. } \\
\text { NO. }\end{array}$ & FACTORS & TOTAL SCORE & MEAN SCORE & RANK \\
\hline 1 & PRICE & 1702.4 & 5.67 & I \\
\hline 2 & CLARITY & 1690.2 & 5.63 & II \\
\hline 3 & CHANNELS & 1557.5 & 5.19 & III \\
\hline 4 & OFFERS & 1311.9 & 4.37 & V \\
\hline 5 & SOUND CLARITY & 1323.5 & 4.41 & IV \\
\hline
\end{tabular}

Source: Primary Data

The table 4 reveals the reasons for selecting the DTH. "Variety of DTH Services" was ranked first by the selected sample respondents with the total score of 1702.4 and mean score of 5.67. "Price" was ranked first with the total score of 1702.4 and mean score of 5.67. "Clarity" occupied second position with the total score of 1690.2 and mean score of 5.63. "Channels" was ranked third with the total score of 1557.5 and mean score of 5.19. "Offers" occupied fifth position with the total score of 1311.9 and mean score of 4.37. "Sound clarity" occupied fourth with the total score of 1323.5 and mean score of 4.41

TABLE 5

RELATIONSHIP BETWEEN AGE AND LEVEL OF SATISFACTION ABOUT CHANNELS CHI SQUARE TEST

\begin{tabular}{|c|c|c|c|c|c|}
\hline \multirow{2}{*}{$\begin{array}{c}\text { Chi } \\
\text { square }\end{array}$} & Cal. Value & Df & P. value & S/NS & $\begin{array}{c}\text { Null } \\
\text { hypothesis }\end{array}$ \\
\cline { 2 - 6 } & 48.880 & 9 & $0.000 *$ & $\mathrm{~S}$ & Rejected \\
\hline
\end{tabular}

It is clear that the $\mathrm{P}$ value is less than $0.05(\mathrm{P}<0.000)$ at $5 \%$ level of significance. Hence, the null hypothesis is rejected. So there is a relationship between age and channels of DTH and also statistically significant. 
TABLE 6

RELATIONSHIP BETWEEN GENDER AND LEVEL OF SATISFACTION ABOUT CHANNELS

CHI SQUARE TEST

\begin{tabular}{|c|c|c|c|c|c|}
\hline $\begin{array}{c}\text { Chi } \\
\text { square }\end{array}$ & Cal. value & Df & P. value & S/NS & Null hypothesis \\
\cline { 2 - 6 } & 27.252 & 3 & $0.000^{*}$ & S & Rejected \\
\hline
\end{tabular}

S-Significant Ns-Not Significant $\quad * P<0.001$

It is clear that the $\mathrm{P}$ value is less than $0.05(\mathrm{P}<0.000)$ at $5 \%$ level of significance. Hence the null hypothesis is rejected. So there is a relationship between gender and channels of DTH and also statistically significant.

\section{TABLE 7}

\section{RELATIONSHIP BETWEEN GENDER AND LEVEL OF SATISFACTION ABOUT CUSTOMERCARE CHI SQUARE TEST}

\begin{tabular}{|c|c|c|c|c|c|}
\hline Chi & Cal. Value & Df & P. value & S/NS & Null hypothesis \\
\cline { 2 - 6 } square & 22.309 & 4 & $0.000^{* *}$ & $\mathrm{~S}$ & Rejected \\
\hline
\end{tabular}

S-Significant Ns-Not Significant $\quad * P<0.001$

It is clear that the $\mathrm{P}$ value is less than $0.05(\mathrm{P}<0.000)$ at $5 \%$ level of significance. Hence, the null hypothesis is rejected. So there is a relationship between gender and customer care of DTH and also statistically significant.

\section{RELIABILITY TABLE}

\begin{tabular}{|c|c|c|c|c|c|}
\hline S. NO. & FACTORS & MEAN & $\begin{array}{l}\text { STD } \\
\text { DEV }\end{array}$ & $\begin{array}{l}\text { SCALE MEAN } \\
\text { ITEM DELETED }\end{array}$ & $\begin{array}{l}\text { ALPHA IF ITEM } \\
\text { DELETED }\end{array}$ \\
\hline 1 & PRICE & 4.2433 & 7656 & 28.1933 & 7992 \\
\hline 2 & CLARITY & 4.3433 & 7879 & 28. 0933 & 8102 \\
\hline 3 & CHANNELS & 4.1167 & 8788 & 28.3200 & 7761 \\
\hline 4 & CUSTOMER CARE & 3.8133 & 1.0142 & 28.6233 & 7583 \\
\hline 5 & PLANS & 3.9400 & 0.9197 & 28.4967 & 7502 \\
\hline 6 & OFFERS & 3.8633 & 0.9314 & 28.5733 & 7725 \\
\hline 7 & SUB CHARGE & 3.8800 & 0.9843 & 28.5567 & 7726 \\
\hline 8 & RECHARGE TIME & 4.2367 & 0.9436 & 28.2000 & 7853 \\
\hline & \multicolumn{4}{|c|}{ NO. OF CASE } & 300 \\
\hline & \multicolumn{4}{|c|}{ MEAN } & 32.4367 \\
\hline & \multicolumn{4}{|c|}{ STD DEV } & 4.6932 \\
\hline & \multicolumn{4}{|c|}{ VARIANCE } & 22.0261 \\
\hline & \multicolumn{4}{|c|}{ ALPHA VA } & 0.8014 \\
\hline
\end{tabular}

From the above table it was clear that, the reliability of scales used in this study was calculated by Cronbach's coefficient alpha. The coefficient alpha values exceed the minimum standard of .70. It's provides good estimates of internal consistency reliability. As shown in the table, coefficient alpha values ranged from .750 to .810 for all the constructs indicating that the scales used in this study were reliable. It should also be noted that an alpha of .8014 is probably a reasonable goal. It should also be noted that while a high value for Cronbach's alpha indicates good internal consistency of the items in the scale, it does not mean that the scale is unidimensional.

\section{SUGGESTIONS}

DTH services are a new concept in the Market and are fast growing and demanding. Here are some suggestions to make it more attractive based on the present study

\section{Greater Customer Orientation}

As the study reveals that there are vast opportunities as well as challenges for DTH services in India, due to technological innovations and significant change in demographic profile of customers, there is huge market potential lying ahead. Hence, in today's competitive environment, Manufacturers will have to strive to attract and retain customers by introducing innovative products, enhancing the quality of customer service and 
marketing a variety of products through diverse channels targeted at specific customer groups. They have to meet the customer expectations on various DTH services.

\section{Creating Awareness}

The study shows that the awareness level of DTH services is restricted to only a certain section of the society. Hence, Manufacturers must concentrate on the needs and demands of various customers depending on their requirements. Advertising the products and explaining the products elaborately will help in attracting more and more people.

\section{Customer Care}

Customers appreciate not only consistencies in services but also hassle free interface with technology. The level of frustration and dissatisfaction escalates when customer encounters problems due to technology either while transacting business on site or off site. When customers file complaint, it must be resolved immediately. From the study, it is inferred that a proper feedback must be provided to the customer regarding the status of the problem. Nowadays customers can directly approach the grievances cell, Consumer Forum for redressal of their complaints. So concentrate on the customer care.

\section{CONCLUSION}

Today DTH is one of the modes of communication through television. There are number of brands in DTH services. They are available in the market, which differs in price, quality, services and variety of packages, type etc.

In the present technology era it can be easily said that all classes of people are using the DTH services to their television for continuous net working. By considering this the DTH producers coming up with different brand names. But the consumers prefer their favorite brands due to various reasons. It can be concluded that the picture quality, advertisement, brand name, channels and price decides the purchase.

The present study reveals that the majority of the respondents prefer to buy sun direct because of its best picture quality, reasonable price, various kinds of packages and more channels. So the DTH service providers must pay attention on Customer Service, picture quality, reasonable price rather than other factors to make their business more successful and satisfy the consumers

\section{BOOKS}

\section{Bibliography}

[1] Dr. S. P. Gupta, Statistical Methods, Sultan Chand \& Sons Educational Publishers, New Delhi-2006.

[2] C. R. Kothari. Research Methodology Methods and Techniques. New Age International (P) Ltd. , publishing New Delhi. Ed-2004.

[3] Philip Kotler, Marketing Management The Millennium Edition, Prentice-Hall of India private limited, New Delhi, Ed -2000.

[4] Marketing Managers Handbook-Britt Guess Second Revised Edition-UBS Publishers Distributors Ltd,New Delhi

\section{JOURNALS}

[5] Indian Journal of marketing

[6] Journal of consumer behavior

[7] Marketing Mastermind

[8] The IUP Journal of Service Marketing

[9] COLLEGE SADHANA Journal for Bloomers of Research

\section{WEBSITES}

[10] Www. sun direct. com

[11] www. tatasky. com

[12] www. bigtv. com

[13] www. airteldigitaltv. com

[14] www. dishtv. com

[15] www. Articlesnatch. com 